\title{
MARGINALIA KOT ZAČETEK PISANE BESEDE: GLOSAS EMILIANENSES
}

Ključne besede: kastiljščina, glose, rokopis, srednji vek

\section{Uvod}

Glosas Emilianenses so opombe v latinščini in romanskem jeziku, ki jih je v 11. stoletju pripisal anonimni menih med vrsticami in na robu besedila v latinskem rokopisu, danes dokumentiranem kot Codex Aemilianensis 60, ${ }^{1}$ predvsem zato, da bi sebi in tistim, ki so besedilo brali za njim, razjasnil skladenjske, oblikoslovne in pomenske težave pri razumevanju izvirnika. Dokument je poimenovan po kraju nastanka, samostanu v vasici San Millán de la Cogolla, ${ }^{2}$ ki velja za »zibelko kastiljščine«: romanske glose v tem kodeksu naj bi bile namreč prve zapisane besede v jeziku, ki se je razvil v današnjo kastiljščino oziroma španščino, in so zato neprecenljivo zgodovinsko, jezikoslovno, literarno in kulturno obeležje. ${ }^{3}$

Njihovo vrednost so odkrili leta 1911, ko je Manuel Gómez Moreno med proučevanjem mozarabske arhitekture samostana prečrkoval vse opombe iz rokopisa in jih poslal znamenitemu jezikoslovcu in medievalistu Ramó-

1 Hranjen v Knjižnici Kraljeve akademije za zgodovino (Biblioteca de la Real Academia de la Historia) v Madridu.

2 V avtonomni pokrajini La Rioja, približno $100 \mathrm{~km}$ vzhodno od Burgosa.

3 Ni odveč poudariti, da ne gre za prve kastiljske besede, ampak za prve zapisane kastiljske besede. Jezik se seveda ne "rodi« določenega leta, ampak je vedno kolektivna stvaritev, ki nastaja skozi stoletja. Poimenovanje San Millána »zibelka kastiljščine« je zato zgolj simbolna oznaka. Še toliko bolj, ker (še vedno) ni povsem dokazano, da so glose res nastale v omenjenem samostanu, ki v tem primeru ostaja le kraj najdbe. 
nu Menéndezu Pidalu. Ta jih je nekaj objavil v svojemu delu Orígenes del español (1926), jih prvi klasificiral in datiral v drugo polovico 10. stoletja, novejši paleografski izsledki (Díaz y Díaz, 1978; Rico, 1978) pa so čas nastanka pomaknili v drugo polovico 11. stoletja, celo po letih 1070-1075 (Hernández Alonso, 1993; García Turza, 2003).

Ne kraj - majhen odročen samostan na severu Španije - ne razmeroma pozen čas nastanka prvega zapisa $\mathrm{v}$ »kastiljščini« v primerjavi $\mathrm{z}$ drugimi romanskimi jeziki nista naključna. Oboje je posledica posebnih zgodovinskih okoliščin na Iberskem polotoku, ki so globoko posegle na vse ravni družbe - versko, politično, gospodarsko, umetnostno in jezikovno. Vdor Mavrov leta 711 je uničil zahodnogotsko kraljestvo s sedežem v Toledu (507-711) in zavrl razvoj krščanske kulture oziroma jo omejil na dve neodvisni jedri na severu - v Kantabriji okrog grofa Pedra ter v Asturiji po zmagi don Pelaya in njegovih mož pri Covadongi $(722)^{4}-$, ki sta več kot sto let uspešno odbijali muslimanske napade. Iz teh dveh jeder se je po smrti asturskega kralja Alfonza II. leta 842 oblikovala grofija Kastilja, ki je spadala pod leonsko kraljestvo. Sprva je bila predhodnica neodvisne ali vsaj avtonomne grofije (931) in pozneje - po razgibanih dogodkih (rivalstva, zavezništva, vojne, poroke) med leonskim in navarskim kraljestvom, v katerih je bila udeležena - kastiljskega kraljestva (1065). Z vsakim od teh dogodkov je povezano po eno zgodovinskoliterarno ime: s prvim Fernán González (okoli 910-970), prvi neodvisni grof in junak pesnitve Poema de Fernán González (13. stoletje), z drugim pa sloviti Rodrigo Díaz de Vivar (1040?-1099), vazal prvega kastiljskega kralja Sancha II. in nato njegovega brata Alfonza VI., junak najpomembnejšega španskega epa Poema de Mio $\mathrm{Cid}^{5}$ in, kot vse kaže, tudi sodobnik anonimnega meniha, ki je zapisal prve španske besede.

Jezik, ki so ga govorili prebivalci tega področja severno in vzhodno od Burgosa, se je razvil iz mešanice tamkajšnjih različic vulgarne latinščine in govoric potomcev ljudi, ki so se zatekli tja po letu $711 \mathrm{~s}$ področja severno od reke Duero, od druge polovice 9. stoletja, ko je arabska nevarnost na tem delu upadla, pa ga skupaj z drugimi prebivalci severnih pokrajin

\footnotetext{
4 Prva zmaga kristjanov proti Arabcem.

5 Slov. prev. Niko Košir: Junaška pesem o Cidu, Cankarjeva založba, 1987.
} 
- med njimi so bili tudi baskovsko govoreči Navarci - ponovno naselili (t. i. »repoblación«). Baskovski jezikovni vpliv je opazen v toponimih, drugače pa je njegova vloga $v$ kastiljščini neznatna, kar je razumljivo, ker gre za dva povsem različna jezikovna sistema in se je manjšinski asimiliral z večinskim. K oblikovanju novega romanskega jezika, predvsem besedišča, je svoje prispevala še mozarabščina, ${ }^{6}$ ki so jo prav tako v drugi polovici 9. stoletja prinesli kristjani z juga, ko so pribežali na to krščansko ozemlje pred državljanskimi vojnami med muslimanskimi zavojevalci (Martínez Díez, 1993, 17-39).

\section{San Millán de la Cogolla}

Provinca La Rioja je bila zaradi svoje geografske lege ves čas na strateškem, političnem, kulturnem in jezikovnem presečišču: leta 923 so bili z njenega ozemlja pregnani Mavri, v naslednjih stoletjih je bila zdaj pod navarskim, zdaj pod leonskim, od leta 1076 pa pod kastiljskim kraljestvom. ${ }^{7}$

Zgodovina samega samostana San Millán seže še veliko dlje, v čas, ko so to področje zasedli Zahodni Goti. Njegov nastanek in ime sta povezana s svetim Emilijanom (473-574). Legenda pravi, da je bil Emilijan preprost pastir iz bližnje vasice Berceo. Nekega dne mu je v mističnem snu angel pokazal pot k puščavniku Feliksu v Bilibio (zaselek na severu Rioje) in ta ga je prepričal, da se je tudi sam posvetil puščavniškemu življenju. V štiridesetih letih, kolikor jih je preživel v naravnih jamah v gorovju Demanda nad Berceom, je s svojim zglednim življenjem in čudeži, ki so mu jih pripisovali, privabljal številne romarje in privržence. Sčasoma se je okoli njega oblikovala skupnost učencev; naselili so se v jami, okoli katere je zrasel zametek samostana, najprej samo oltar in oratorij, potem pa preprosta bazilika. Tudi po učiteljevi smrti se je njegova slava hitro širila. Na četrtem toled-

6 Romanski dialekti tistih prebivalcev na ozemlju kalifata Al-Andalus, ki so v vsakdanjem življenju privzeli navade zavojevalcev, vendar so ohranili tako vero kot jezik. Za zapis mozarabščine so uporabljali arabsko pisavo. Arabski superstrat je kastiljščino močno zaznamoval, saj se je vanjo integriralo približno štiri tisoč arabskih besed, predvsem samostalnikov, ki označujejo konkretne predmete s področja poljedelstva in raznih obrti.

7 Prvič od 1076 do 1109, drugič od 1135 do 1162 in dokončno leta 1167. 
skem koncilu leta 634 so ga razglasili za svetnika, že leta 650 pa je zaragoški škof Braulio napisal njegovo prvo biografijo. ${ }^{8} \mathrm{~V}$ drugi polovici 10. stoletja je samostan postal pomemben romarski kraj. V naslednjih stoletjih so na grob svetega Emilijana prihajali tudi številni romarji na poti v Santiago de Compostela, saj je bil San Millán le nekaj deset kilometrov odmaknjen od utečenih poti v sveti kraj.

Samostan se je z leti širil in je danes svojevrsten umetniški spomenik, saj se v njem prepletajo oziroma sobivajo najrazličnejši arhitektonski slogi: od zgodnjekrščanskega, mozarabskega (prva polovica 10. stoletja) do romanskega (od začetka 11. do konca 12. stoletja), ki pričajo o razgibani zgodovini kraja. ${ }^{9}$ Najhujši udarec je doživel leta 1002, ko ga je na svojem zadnjem udarnem pohodu uničila Al-Mansurjeva vojska, največji razcvet pa nekaj desetletij pozneje, torej malo pred nastankom glos, ko je pod svoje okrilje združil več sosednjih samostanov. ${ }^{10}$

8 Šest stoletij pozneje se je pesnik Gonzalo de Berceo (1196?-1264?) oprl na to besedilo, ko je ovekovečil svetnikov lik v hagiografski pesnitvi Vida de San Millán de la Cogolla [Življenje svetega Millána (Emiliana) iz Cogolle]. Berceo, prvi španski pesnik, čigar ime je znano, je bil tesno povezan s samostanom San Millán: $v$ njem se je izšolal in bil nekaj časa menih, tam naj bi tudi ustvaril svoje najpomembnejše delo Milagros de Nuestra Señora [Čudeži naše Gospe].

9 V 11. stoletju je samostan postal premajhen, in ker teren ni več dopuščal širitev, so nekoliko nižje v dolini zgradili večji objekt. Ta del se je poimenoval »de Yuso « (spodnji), za prvotnega pa je obveljalo ime »de Suso« (zgornji). Spodnji je v 13. stoletju pogorel, ohranjena je renesančna arhitektura iz 16. stoletja. Danes je San Millán de Suso pod Unescovo zaščito.

$10 \mathrm{~V}$ tistem času je bil nekaj let prior Dominik, ki ga je Fernando I. leta 1041 imenoval za opata bližnjega samostana Silos (danes Santo Domingo de Silos). V tem samostanu so le nekaj let za Emilianenses nastale druge najpomembnejše glose v romanskem jeziku, Glosas Silenses. 


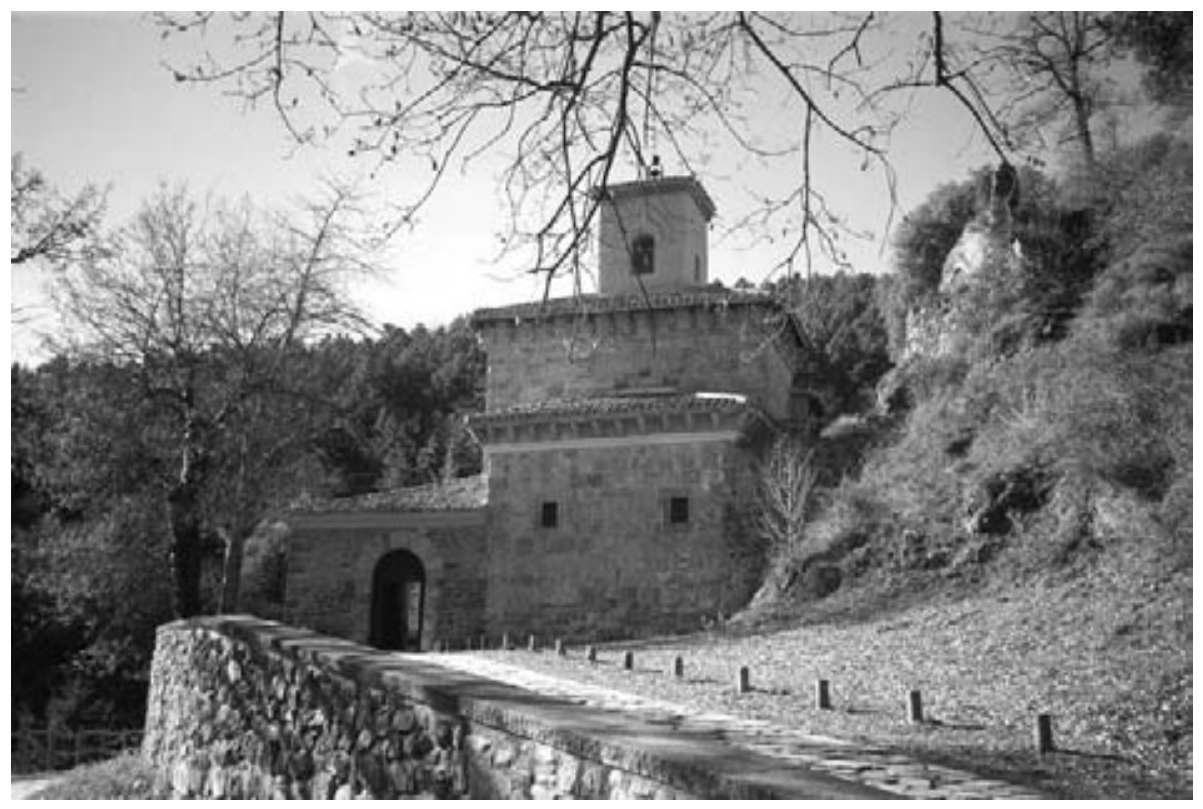

slika 1: Samostan San Millán de la Cogolla vir: M. Šabec

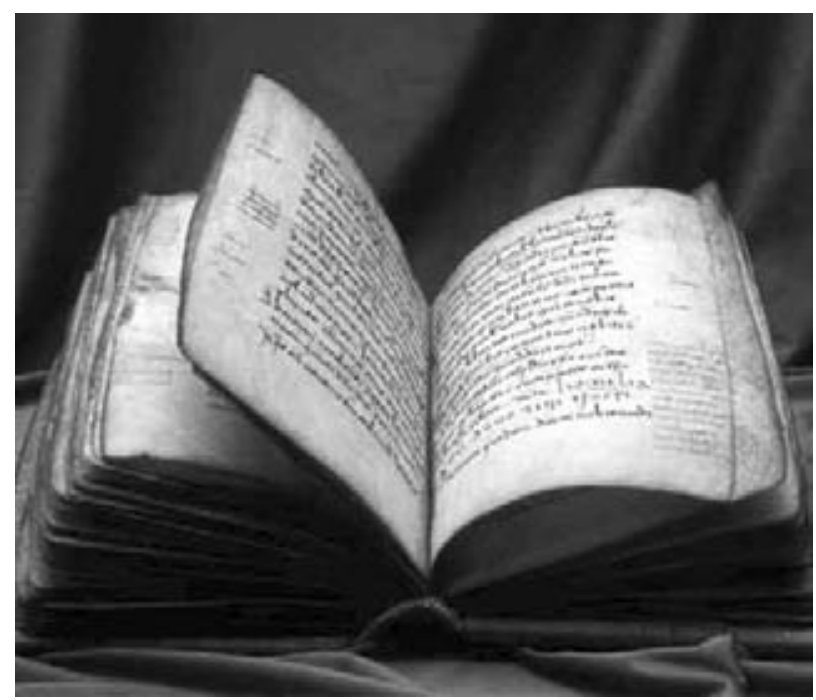

slika 2: Codex Aemilianensis 60

Biblioteca de la Real Academia de la Historia, Madrid vir: www.culture-routes.lu/.../0000000385_1.jpg 


\section{Codex Aemilianensis 60}

Codex Aemilianensis 60 je nastal med koncem 9. in začetkom 11. stoletja, morda v sanmillanskem skriptoriju, morda pa je prišel v tamkajšnjo knjižnico iz kakšnega bližnjega samostana. Kodeks je majhen, približno velikosti današnjih žepnih knjig. Meri 188,5 mm x 137 mm in šteje sedemindevetdeset listov. Tudi sicer je dokaj siromašen: pergament je slabe kvalitete, neenakomerne debeline in na nekaterih mestih so zaradi slabe izdelave ostale luknje. Napisan je v zahodnogotski minuskuli ali vizigotiki, ${ }^{11} \mathrm{v}$ običajni kaligrafiji s temno oker barvo, nima niti ene miniature, le začetnice so ponekod okrepljene in obarvane $\mathrm{z}$ rdečim ali zelenim črnilom. Kopistovo ime je znano - Munio -, ker se je na dveh mestih "podpisal «. ${ }^{12}$

Besedilo združuje raznovrstne verske spise: življenja svetnikov (fol. 1-28r.), litanije (fol. 28v.-29r.), pasijon svetih Kozme in Damijana ter mašo in molitve ob njunem dnevu (fol. 29v.-54v.), knjigo sentenc (fol. 55r.-67r.) ter nekaj pridig in homilij, pripisanih svetemu Avguštinu (fol. 67v.-96v.) (Hernández Alonso, 1993, 63). Zaradi takšne tematske raznolikosti in tehničnih značilnosti (vezava, ponekod napačno številčenje strani ipd.) je možno, da je bil kodeks že v srednjem veku sestavljen iz izvorno različnih kosov, čeprav jih je napisala ista roka (Ruiz Asencio, 1993, 87).

\section{Glose}

Glose so pripisane samo na enaintridesetih listih oziroma straneh, in to na treh različnih delih kodeksa. Kaligrafija je manjša in tanjša od tiste v rokopisu, uporabljeno pa je črno črnilo. Glede števila glosatorjev si raziskovalci niso povsem enotni. Sodeč po pisavi, nekateri sklepajo, da je opombe in razlage $\mathrm{k}$ latinskemu besedilu naknadno pripisoval en sam avtor (Ruiz Asencio, 1993), drugi pa, da sta bila dva (Díaz y Díaz, 1978, 27-29).

11 S primesmi karolinške minuskule (sistem okrajšav), kar je tudi glavni kriterij pri dataciji rokopisa (Ruiz Asencio, 1993).

12 »Hec est uia et opus monaci. Munnioni presbiter librum « in "Munnionem indignum memorare pusillum «. 
Treba je poudariti, da so te glose res ključnega pomena za poznavanje najstarejših materialnih dokazov o romanski stopnji razvoja latinščine $\mathrm{v}$ sodobno kastiljščino, vendar niso ne glavni del ne središče tega rokopisa: med pripisi k izvirniku - teh je več kot tisoč - namreč prevladujejo praktične slovnične opombe, le okoli sto petdeset pa je leksičnih - latinskih, romanskih in baskovskih pojasnil ali prevodov, torej glos $\mathrm{v}$ pravem pomenu besede. $\mathrm{K}$ tem prištevamo še manjše število komentarjev, nekakšnih opomnikov, ki jih je menih beležil ob branju in napotujejo na določen del besedila drugje v rokopisu ali na potrebno tematsko osvetlitev.

Ves ta »razlagalni aparat«, ki obsega sintaktično, morfološko in semantično raven, kaže na hipotezo, da gre za očiten primer metode poučevanja latinščine (Rico, 1978; Hernández Alonso, 1993, 76): menih učitelj je izbral nekaj odlomkov za učno uro in jih skrbno opremil z elementi slovnične analize, ${ }^{13}$ manj znanim besedam določil sopomenko v latinščini ali jih, zelo redko, pojasnil $z$ besedo ali opisom $v$ romanskem jeziku, tu in tam pa dodal še krajšo vsebinsko razlago. Pri učni uri je nato redovniškim novicem bral in razlagal snov ob rokopisu, seveda vselej v latinščini, saj je vse obredje in poučevanje v samostanu potekalo v tem jeziku (Hernández Alonso, 1993, 67). Rico (1978) podkrepi didaktično namembnost tega "priročnika« še z dejstvom, da gre za zelo skromen kodeks na slabem pergamentu, ne za dragoceno iluminirano rokopisno knjigo, s kakršnimi so se sicer ponašali srednjeveški skriptoriji, tudi tisti v San Millánu. ${ }^{14}$

Opombe so največkrat pripisane neposredno med besedilom ali ob njem, redkeje so uvedene s španskim predlogom por ali latinsko sintagmo id est. Tiste, ki pojasnjujejo posamezno besedo, so včasih dobesedne, še večkrat pa razširijo ali posplošijo njen pomen in izražajo pravo konotacijo šele v neposrednem kontekstu (na primer OSCULUM: salutare). Eno besedo lahko pojasnjuje tudi več izrazov ali cel stavek in obratno. $\mathrm{Z}$ jezikoslovnega

13 Grafične oznake (križci) nad besedo označujejo začetek in konec stavka ali dela stavka, črke $a, b, c, d$ itd. nad besedami razvezujejo latinski besedni red v romansko skladnjo, vprašalni zaimki pa osvetljujejo stavčne člene: qui za osebek, ke za predmet v četrtem sklonu; če pred njim stoji predlog in, de, za prislovno določilo, za prislovno določilo načina quomodo itn.

14 Za podroben pregled iluminiranih rokopisov sanmillanskega skriptorija glej: María Soledad I. de Silva y Verástegui, Iconografía del siglo X en el reino de Pamplona-Nájera, Diputación Foral de Navarra, 1984, in druga dela iste avtorice. 
vidika so seveda najzanimivejši primeri, ko je glosator "prevedel « ne le eno besedo, temveč sintagmo ali kar cel stavek iz izvirnika $\mathrm{z}$ ustrezno romansko strukturo, ker zelo nazorno kažejo, koliko se je govorjena latinščina že oddaljila od klasične. ${ }^{15}$

Glede na jezik zapisa se glose torej delijo na latinske (teh je največ), romanske in dve baskovski. ${ }^{16}$

\subsection{Latinske glose}

V spodnji razpredelnici je nekaj primerov latinskih glos, bodisi sopomenk bodisi razlag latinskih besed $\mathrm{v}$ latinščini. Morda je raba določene latinske besede $\mathrm{v}$ tistem času že upadala ali pa se je menih ravnal po občutku in uporabil izraz, ki se mu je zdel bolj razumljiv. Ne glede na njegovo odločitev se izkaže, da so se nekatere latinske besede iz izvirnika ohranile vse do današnje španščine, vsaj kot kultizmi (na primer JNCOLOMES - sanos et salbos - incólumes, intactos), medtem ko so tiste, ki jih je izbral glosator, utonile v pozabo ali se ohranile kot dvojnice (na primer DIUISIONES - partitjones - divisiones, partes), v nekaterih primerih pa se ni ohranila nobena od različic oziroma je prevladala tretja (na primer BELLUM - pugna - lucha).

15 Pri tem je treba kljub vsemu upoštevati, da gre v glosah bolj za učeno ljudsko kakor za ljudsko vulgarno različico jezika (Hernández Alonso, 1993, 65). Glej tudi op. 21.

16 Baskovski glosi pomenita - tako kot romanske glose za španščino - prvi pisni dokaz v tem jeziku ter hkrati pričata, da je bil glosator baskovskega oziroma navarskega rodu in se je najverjetneje malo pred tem naučil romanskega jezika. Za baskovski glosi glej predvsem dve študiji: Líbano Zumalacárregui, Á., Las variedades lingüísticas en el País Vasco: romance y vasco en la Edad Media, v: Actas del IV Congreso Internacional de Historia de la Lengua española (ur. José Luis Girón Alconchel, José Jesús de Bustos Tovar), vol. 3, 2006, 3013-3020; in Guiter, E., Nota sobre el vascuence de las »Glosas Emilianenses", Cuadernos de investigación filológica, 5, 1979, 145-148. 


\begin{tabular}{|l|l|l|l|}
\hline LATINŠČINA & LATINSKA GLOSA & SODOBNA ŠPANŠČINA & SLOVENŠČINA \\
\hline BELLUM & pugna & lucha & vojna \\
\hline DIUISIONES & partitjones & divisiones, partes & deli \\
\hline JNCOLOMES & sanos et salbos & incólumes, intactos & nepoškodovani \\
\hline ADULTERIUM & fornicatjonem & adulterio, infidelidad & nezvestoba, prešuštvo \\
\hline CRIMINIS & peccatos & pecados & krivda, zločin \\
\hline JMPERIUM & mandatjione & mando & ukaz, predpis \\
\hline CERTAMINA & pugna & lucha & boj, prepir \\
\hline INERMIS & sine arma & indefenso, desarmado & neoborožen \\
\hline
\end{tabular}

Komentiranje/glosiranje latinskih rokopisov v 11. stoletju ni bila nikakršna novost. V romanskem svetu je bilo zelo razširjeno že več stoletij, od 10 . stoletja pa so krožili tudi številni glosarji, ki so jih avtorji sestavljali iz obstoječih opomb v rokopisih. Nekateri raziskovalci (Díaz y Díaz; Rico) celo menijo, da je glosator sanmillanskega rokopisa uporabljal katerega od takih glosarjev, vendar drugi (Wright) ${ }^{17}$ to možnost zavračajo, saj iz 11. stoletja še ni pričevanj o obstoju latinsko-romanskih glosarjev (ti so se množili šele od 13. stoletja); obstajali so zgolj latinski glosarji, torej nekakšni slovarji sinonimov. Predvsem pa menijo, da glosator glede na svoje odlično poznavanje latinščine glosarja tako in tako ni potreboval (Hernández Alonso, 1993, 71-72).

\subsection{Romanske glose}

Še vedno ni povsem pojasnjeno, zakaj se je glosator v nekaterih - za današnje jezikoslovce najdragocenejših - primerih odločil pretrgati tradicijo opomb v latinščini, ki jo je nedvomno obvladal in jo najverjetneje tudi poučeval, in latinsko besedo ali sintagmo prevesti v romansko različico. Hernández Alonso $(1993,74,82)$ domneva, da je šlo za zavestno reakcijo proti clunyjski družbeno-kulturni reformi, ki je ob podpori kastiljske krone čeda-

17 Wright, R., Late Latin and Early Romance in Spain and Carolingian France, Liverpool, 1982. 
lje bolj pritiskala na benediktinske samostane. ${ }^{18}$ Ruiz Asencio $(1993,108)$ pa to (nezavedno) glosatorjevo odločitev pripisuje splošnemu pomanjkljivemu znanju latinščine neposredno pred prihodom in utrditvijo clunyjcev.

$\mathrm{V}$ romanskih glosah je latinska pisava prilagojena načinu izgovorjave ljudskega jezika, vendar je njihov zapis, razumljivo, nenatančen in nedosleden. Pa tudi sicer je snovi premalo, da bi v njej sistematično opazovali »kastiljščino « 11. stoletja. Glosator je za isti fonem uporabil različne grafeme, zato ni vedno jasno, kako se je izgovarjal. ${ }^{19}$ Obstajali so tudi glasovi, ki jih latinščina ni poznala, kar je bila še dodatna težava, saj je moral sam najti način, kako jih zabeležiti. Pomemben dejavnik, ki ga je treba upoštevati, je tudi splošna konzervativnost pisave. Latinizirani pravopis zato ne more biti zanesljiv pokazatelj prisotnosti oziroma odsotnosti določene oblike ali glasu v govorjenem jeziku. ${ }^{20}$

18 V 11. stoletju se je clunyjski red (ustanovljen 910) zelo okrepil. S porokama Alfonza VI. (1065-1109) najprej $\mathrm{z}$ akvitansko in nato $\mathrm{z}$ burgundsko princeso se je njihov politični in kulturni vpliv prenesel tudi v kraljestvo Kastilje in Leóna. Tako so, denimo, vpeljali karolinško pisavo, ki je spodrinila gotski rokopis, spodbujali so učenje latinščine in zamenjali vizigotsko-mozarabsko liturgijo $\mathrm{z}$ rimsko. $\mathrm{V}$ številnih samostanih so to kulturno reformo sprejeli z odporom. Morda je šlo za takšno lokalno reakcijo tudi v sanmillanskem primeru in je želel menih glosator obeležiti avtohtoni dialekt, ki je bil drugačen od tistega v Kastilji.

19 Isti glas ni vedno zapisan na isti način. Različne oblike glagola JACTARE vidimo zapisane enkrat zetare, drugič geitat ali jectatis (Hernández Alonso, 1993, 75).

20 Če je na primer latinska beseda LOCO zapisana lueco, je nespodbitno, da je kratki naglašeni kratki $o$ že diftongiral $\mathrm{v} u e$; toda $c$ ne pomeni nujno, da se je velarni zapornik izgovarjal nezveneče, temveč da ga je učeni menih morda zapisal na latinski način, kar je še toliko bolj verjetno, ker se v notarskih besedilih iz istega časa pojavlja luego. Nasploh je pri zapisu dvoglasnikov veliko oklevanja. Oblike uemne, uamne, huamne pričajo o besedi v procesu fonetičnega razvoja; glosator ne zna natančno transkribirati samoglasnika, verjetno zato, ker je zvenel med širokim $e$ in $a$, ali pa zato, ker so ga eni izgovarjali tako in drugi drugače (v San Millán so prihajali menihi iz okoliških pokrajin, vsak s svojo govorno različico) (Hernández Alonso, 1993, 76). Zapis soglasnikov je še bolj nepregleden. Za mehkonebni nosnik [n] Pidal navaja vsaj osem različnih grafij: ni, in, ng, gn, nig, nn, n; nič manj za $[\lambda]$ in [š]. Nemi [s] in zvočni [z] se v zapisu pogosto zamenjujeta, popolna zmeda vlada med ustničnim zapornikom [b] in pripornikom [v] itd. (Pidal, 1972, 49 in nasl.). 


\begin{tabular}{|l|l|l|l|}
\hline LATINŠČINA & ROMANSKA GLOSA & SODOBNA ŠPANŠČINA & SLOVENŠČINA \\
\hline ECCE REPENTE & lueco & luego, en seguida & takoj, potem \\
\hline SUBMERSI & trastorne & trastorné & sem potopil \\
\hline INDICA & amuestra & muestra, explica & kaže, izraža \\
\hline CARACTEREM & seignale & señal, signo, marca & znak \\
\hline CURSILES & correnteros & corrientes, torrentes & tokovi, hudourniki \\
\hline $\begin{array}{l}\text { ET TERTIUS [...] } \\
\text { UENIENS }\end{array}$ & elo terzero [diabolo] uenot & y el tercer [diablo] vino & $\begin{array}{l}\text { in tretji [hudič] je } \\
\text { prišel }\end{array}$ \\
\hline $\begin{array}{l}\text { PAUPERIBUS } \\
\text { REDDET }\end{array}$ & qui dat alos misquinos & que da a los pobres & ki daje revnim \\
\hline TU JPSE ES & tu eleisco jes & tú mismo eres & ti sam si \\
\hline
\end{tabular}

Za jezikoslovce pomeni posebno težavo poimenovanje različice romanskega jezika, v katerem so glose zapisane. Menéndez Pidal $(1926,470)$ jo je opredelil kot »riojansko govorico 10 . stoletja, zelo prežeto z navarskoaragonskimi značilnostmi . $^{21}$ Če pustimo ob strani Pidalovo datacijo v 10. stoletje, se mnenja nekaterih raziskovalcev razlikujejo od njegovega tudi glede deleža dialektalnih vplivov. Hernández Alonso $(1993,75,82)$ na primer poudari kastiljski segment in opusti navarsko-aragonskega: »ljudski kastiljsko-riojanski dialekt druge polovice 11. stoletja s tendencami učene latinščine«. García Turza (1995) takšnemu poimenovanju nasprotuje in, sklicujoč se na Pidala, poudarja, da gre primarno za riojansko, kvečjemu visokoriojansko govorico (»habla altorriojana«), ki ima več skupnega $\mathrm{z}$ drugimi sosednjimi dialekti (aragonskim, navarskim, leonskim in mozarabskim) kot s kastiljščino. Presečišče vseh definicij je vendarle riojanska različica, njena temeljna značilnost pa prav jezikovni sinkretizem. Ker vsebuje tudi kastiljske komponente, ker so sanmillanske glose "prvi pisni pojav nečesa, kar ni latinščina in je podobno kastiljščini« (García Turza, 1992), in nenazadnje, ker so nastale na ozemlju, ki je prav v tistem času

21 Bolj arhaične oblike: na primer nesonorizirani zaporniki v medsamoglasniškem položaju; ohranjene soglasniške skupine $p l, c l, f l$; ohranjeni začetni $f$ itd. (Pidal, 1926, 470-471). Glej tudi prejšnjo opombo. 
formalno postalo kastiljsko, so po konvenciji obveljale za "prvi zapis v kastiljščini« - jeziku, ki je v prihodnjih stoletjih prerasel v nacionalni jezik kastiljskega kraljestva.

\subsection{Glosa št. 89}

Najdaljša in najcelovitejša romanska glosa $\mathrm{v}$ sanmillanskem rokopisu je št. $89^{22}$ na 72. listu (fol. 72r). Izvirno besedilo je sklepni del homilije svetega Cezarija, na desnem robu pa ga dopolnjuje vsebinsko bogat in jezikovno zanimiv glosatorjev dostavek; ta je več kot kombinacija parafraze in prevoda, torej več kot glosa - vsebuje namreč stavek, s katerim je menih nadgradil obredni obrazec iz izhodiščnega besedila v vznesen hvalospev ali prošnjo Bogu. In prav ta dodatek velja za prvo izvirno špansko besedilo v pravem pomenu besede. Ne le da se ne naslanja na nobeno predlogo, pripisati mu je mogoče celo poetično vrednost, saj je edinstven dokaz ustvarjalne moči, ki je meniha spodbudila, da je s svojimi besedami v »svojem « jeziku izrazil globoko vdanost Bogu. ${ }^{23} \mathrm{~V}$ spodnjem prikazu je ta del zapisan odebeljeno.

22 Številčenje po Pidal $(1926,7)$.

23 Rico (1978) opozarja, da ne gre spregledati (morda naključnega) dejstva, da se najizvirnejši pripis v rokopisu nahaja prav na robu pridige svetega Cezarija; arlski škof $\mathrm{z}$ začetka 6. stoletja je namreč poudarjal nujnost pridiganja v ljudstvu razumljivem jeziku. 
Besedilo v latinščini:
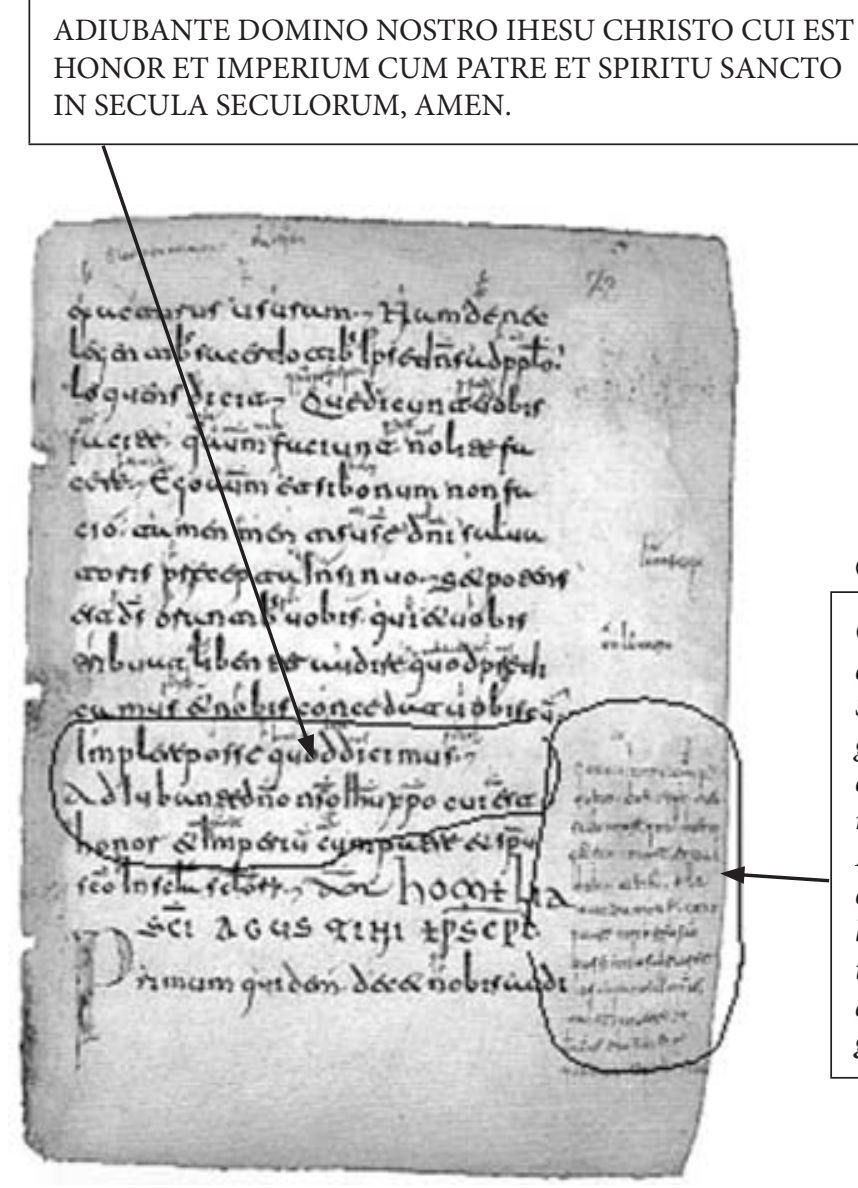

Glosa v romanskem jeziku: ${ }^{24}$

Cono ajutorio [de] nuestro dueno dueno Christo dueno Salbatore qual dueno get ena honore e qual duenno tienet ela mandatjone cono Patre cono Spiritu Sancto enos sieculos delo siecu los. Facanos Deus omnipote(n)s tal serbitjo fere ke denante ela sua face gaudioso segamus. Amen. ${ }^{25}$

slika 3: Codex Aemilianensis, fol. 72r., glosa 89 vir: jonkepa.files.wordpress.com/2008/07/castella.jpg

24 Tukajšnja transkripcija glos sledi izvirni razporeditvi besed v vrstice (vključno $\mathrm{z}$ »deljenjem « sieculos), okrajšave »nso (nostro), »xpm « (Christum), »spu sco« (espíritu sancto), »ds« (Deus), »ompes« (Omnipotens), »am « (amen) pa so izpisane s celo besedo

25 S pomočjo našega Gospoda, gospoda Kristusa Odrešenika, Gospoda, ki je v slavi, in Gospoda, ki vlada z Očetom in Svetim Duhom, na veke vekomaj. Stori vsemogočni Bog, da ti bomo služili tako, da bomo radostni pred tvojim obličjem (ali: Naj vsemogočni Bog stori, da mu bomo služili tako, da bomo radostni pred njegovim obličjem.) Amen. (Prev. M. Š.) 
Kljub številnim izčrpnim študijam sanmillanskega rokopisa veliko podrobnosti iz te glose še ni povsem pojasnjenih. V kratki jezikovni analizi besedila bomo povzeli le nekaj glavnih leksičnih, fonetičnih, morfoloških in sintaktičnih značilnosti "novega « jezika, tako tistih, ki ponazarjajo njegov (bistveni) odmik od latinščine, kot onih, ki kažejo na njegovo arhaičnost; nekateri arhaizmi so skupni razvoju večine jezikovnih različic na Iberskem polotoku, nekateri dokazujejo navarsko-aragonsko komponento, nekateri pa so le odsev glosatorjevih oklevanj, kako zapisati določeno obliko. ${ }^{26}$

Besedišče v glosi je izrazito konzervativno. Latinska beseda IMPERIUM, denimo, ni prevedena $\mathrm{v}$ romansko različico, temveč je uporabljena latinska sopomenka mandatjone. [Spiritu] Sancto je učeni latinizem in ostaja nespremenjen. Glosator je uporabil stalno latinsko besedno zvezo tudi v svojem, torej dodanem delu (deus omnipotens).

Med glasovnimi spremembami so razumljivo najpogostnejše tiste, ki so tudi najstarejše. Kratka naglašena $o$ in $e$ diftongirata $\mathrm{v}$ ue oziroma ie (DOMINU $\rightarrow$ dueno, NOSTRO $\rightarrow$ nuestro, SECULA $\rightarrow$ sieculos). Nenaglašeni samoglasnik med dvema soglasnikoma praviloma izpade (spet DOMINU $\rightarrow$ dueno); to ne velja za latinizem spiritu, prav tako ni sinkope v polučeni besedi sieculos (morda pri izgovorjavi). Palatal $j \mathrm{v}$ mandatjone in serbitjo verjetno zmehča predhodni $t$, da postane zobnodlesnični zlitnik. Čutiti je omahovanje med ustničnim zapornikom [b] in pripornikom [v]: salbatore, serbitio. Znak arhaičnosti je, da se soglasnik v medsamoglasniškem položaju ne sonorizira (aiutorio, salbatore, patre, facanos). V tretji osebi glagola ESSE $e$ diftongira: EST $\rightarrow$ get (izg. [jet]), kar je riojanska posebnost. Predlog denante ohranja etimološki nosnik iz DE IN ANTE.

V oblikoslovju je vidnejša razvojna sprememba glede na latinščino funkcija romanskega člena elo, ela, elos, elas (zgoraj v razpredelnici elo terzero diabolo, tukaj ela mandatione, ela sua face), ki se tudi spaja s predlogom; če se predlog konča na $n$, člen ne le izgubi začetni $e$, temveč se $l$ asimilira $\mathrm{z} n$ (cono aiutorio, ena honore). Člen ostaja tudi v kombinaciji s svojilnim pridevnikom: la sua face. Samostalniki ohranjajo končni $e$ : honore, Salbatore, mandatione. Honore poleg tega obdrži latinski ženski spol. Množinska

26 V nadaljevanju povzeto po Pidal (1926), García Turza (2003), Hernández Alonso (1993). 
končnica $s$ je izražena pri samostalnikih, pridevnikih in glagolih v prvi osebi množine (sieculos, segamus), razen če stojijo pred glagolom ser, ker se ta začne na $s$ (gaudeoso segamus). Isto se zgodi s členom los $\mathrm{v}$ sintagmi delo sieculos. Oziralni zaimek qual nadomešča qui, lahko tudi que ali quien. Glagol $\mathrm{v}$ tretji osebi ohranja obrazilo -t: get, tienet. Zanimivo je, da se v prvi osebi množine - najverjetneje zaradi tendence $k$ latiniziranju - ohranja obrazilo -mus, čeprav je že prej krožila oblika -mos. Podobno kot pri samostalnikih se tudi v nedoločnikih ohranja končni $e$ : FACERE $\rightarrow$ fere. Oblika segamus je konjunktiv glagola SEDERE, iz katerega se je oblikoval glagol ser.

Skladenjska razmerja komaj presegajo sintagme in preproste stavke, kar je pri tako kratkem besedilu razumljivo. Eden od prepričljivih dokazov, da je menih dejansko obvladal latinščino, je njegov dvojni prevod latinske oblike ESSE + dativ. Enkrat jo je razvezal v glagol in prislovno določilo CUI EST HONOR ET IMPERIUM $\rightarrow$ qual dueno get ena honore, v nadaljevanju $\mathrm{v}$ istem stavku pa jo je prevedel $\mathrm{z}$ glagolom imeti (tener) in predmetom $\mathrm{v}$ tožilniku: qual duenno tienet ela mandatione. ${ }^{27}$ Samostalnik dueno v sintagmi nuestro dueno dueno Christo se morda ponovi zaradi slovnične jasnosti, morda pa kot emfatični znak ljudske govorice. Latinski rodilnik saeculorum je zamenjala predložna zveza: de lo sieculos. Skladenjski latinizem je položaj glagola na koncu stavka (gaudioso segamus, facanos [...] tal serbitio fere). Oblika facanos [...] fere je zanimiva kot kavzativna struktura z glagolom hacer in tudi zato, ker je nepoudarjeni zaimek prilepljen na koncu glagolske oblike.

\section{Sklep}

Glosas Emilianenses veljajo za prvi materialni dokument o obstoju romanskega jezika, ki se je razvil v današnjo španščino. Čeprav okoliščine nastanka (točen čas, kraj in namen) še niso povsem potrjene in si raziskovalci tudi glede interpretacije nekaterih glos niso enotni, imajo ti drobni

27 Hernández Alonso $(1993,69)$ domneva, da je glosator začutil pomensko razliko: HONORE (čast) je razumel kot nekaj neločljivo povezanega s Kristusom, IMPERIUM oziroma mandatione pa kot oznako ad extra in jo je zato prevedel kot značilnost, ki jo ima. 
zapisi za špansko kulturno zgodovino velik simbolni pomen. Nastali so v 11. stoletju na severu Iberskega polotoka, tako rekoč hkrati z zametkom kastiljskega kraljestva - njihov jezik je torej tudi jezik legendarnih junakov, ki so jih opevale prve epske pesnitve. V naslednjih dveh stoletjih je postal pomemben jezik kulture in literature. Okrepila se je tudi jezikovna zavest in sledil je prvi poskus poenotenja - »castellano drecho" Alfonza X. Modrega -, ki je pripravil teren za prvo slovnico španskega jezika - La Gramática de la lengua castellana Antonia Nebrije (1492), temeljnega dela, ki je tudi formalno ukoreninilo kastiljščino kot jezik španskega kraljestva in kmalu tudi južnoameriške celine. 


\section{LITERATURA}

Díaz y Díaz, M., Las primeras glosas hispánicas, Barcelona, 1978.

García López, J., Clavería C., Gonzalo de Berceo: Obras Completas, Madrid, 2003.

García Turza, C., La datación y procedencia de las Glosas Emilianenses y Silenses: anotaciones críticas a los nuevos planteamientos, Brocar 19, 1995, 49-64 (www.vallenajerilla.com/berceo/garciaturza/anotacionesglosas.htm).

García Turza, C., La glosa 89 del Em. 60, 'el primer vagido del español'. Estudis Romanics 25, 2003, 299-310

(www.vallenajerilla.com/berceo/garciaturza/glosa89delem60.htm).

García Turza, C., Muro, M. Á. (ur.), Glosas Emilianenses, Testimonio, 1992 (www.vallenajerilla.com/berceo/turzamuro/glosasemilianenses.htm).

Grande Quejigo, F. J., Hagiografía y difusión en la Vida de San Millán de la Cogolla de Gonzalo de Berceo, Logroño, 2000.

Hernández Alonso, C., Las glosas. Interpretación y estudio lingüístico, v: Las Glosas Emilianenses y Silenses, Edición crítica y facsímil (ur. César Hernández Alonso), Burgos, 1993, 63-82.

Martínez Díez, G., El Condado de Castilla y los monasterios de Santo Domingo de Silos y San Millán de la Cogolla, v: Las Glosas Emilianenses y Silenses, Edición crítica y facsímil (ur. César Hernández Alonso), Burgos, 1993, 17-39.

Martínez Ruiz, E., Atlas Histórico de España I, Madrid, 2003.

Pidal, R. M. [1926], Orígenes del español. Obras completas, VIII, Madrid, 1972.

Rico, F., El cuaderno de un estudiante de latín, Historia 16 3, 25, 1978, 7578 (www.vallenajerilla.com/glosas/rico.htm).

Ruiz Asencio, J. M., Hacia una nueva visión de las Glosas Emilianenses y Silenses, v: Las Glosas Emilianenses y Silenses, Edición crítica y facsímil (ur. César Hernández Alonso), Burgos, 1993, 83-118.

Wolf, H. J., Las Glosas Emilianenses, otra vez, Revista de Filología Románica , 14, 1, 1997, 597-604 (www.vallenajerilla.com/berceo/wolf/emilianensesotravez.htm). 


\section{MARGINALIA AS THE BEGINNING OF WRITTEN CULTURE:}

\section{THE GLOSAS EMILIANENSIS}

Keywords: Castilian, glosses, manuscript, Middle Ages

\section{Abstract}

The Glosas emilianenses are notes in Latin and in a Romance language dating from the eleventh century, written by an anonymous monk between the lines and in the margins of a Latin manuscript known as Codex Aemilianensis 60 to explicate syntactic, morphological, and semantic difficulties in understanding the original. The document was named after its place of origin, a monastery in the village of San Millán de la Cogolla, known as "the cradle of Castilian." The non-Latin Romance glosses are believed to be the first written accounts of the language that later evolved into presentday Castilian or Spanish; they are therefore invaluable historical, linguistic, literary, and cultural material.

The place and time of the origin of the glosses are not a coincidence, but a consequence of particular historical circumstances in the Iberian Peninsula. The Moorish invasion in $711 \mathrm{AD}$ destroyed the Visigothic Kingdom and constrained the development of Christian culture, confining it to two independent cores in the north. The ninth century therefore saw the establishment of the County of Castile emerging from the two cores as the predecessor of the Kingdom of Castile (1065). Due to turbulent historical events, the place was populated by people from various adjacent and rather distant countries, thus making the spoken language a mixture of several varieties of Vulgar Latin, Mozarabic, and Navarrian (Basque) elements.

All of these features are reflected in the glosses in the San Millán manuscript. Therefore, it is difficult for linguists to name the variant of the Romance language the glosses were written in: "the Riojan dialect," "a vernacular Castilian-Riojan dialect of the second half of the eleventh century displaying tendencies towards learned Latin," or "a Riojan dialect with elements more common to neighboring dialects (Aragon, Navarrian, Léon, 
and Mozarabic) than to Castilian." However, because the San Millán glosses also include elements of Castilian (after all, they are "the first written account of something that is not Latin, but rather similar to Castilian"), and because they were produced in the area during the period formally established as Castilian, they became known as "the first written accounts of Castilian."

The Latin script in the glosses follows the manner of pronouncing the vernacular, but the written account is understandably inaccurate and inconsistent. In addition, there is insufficient material available to systematically identify the "Castilian" of the eleventh century. Nevertheless-or perhaps precisely for this reason-the glosses are a challenge for linguists, who still have not succeeded in working out all the lexical, phonetic, morphological, and syntactic issues raised by the text. This also applies to the longest and most informative gloss, number 89. 


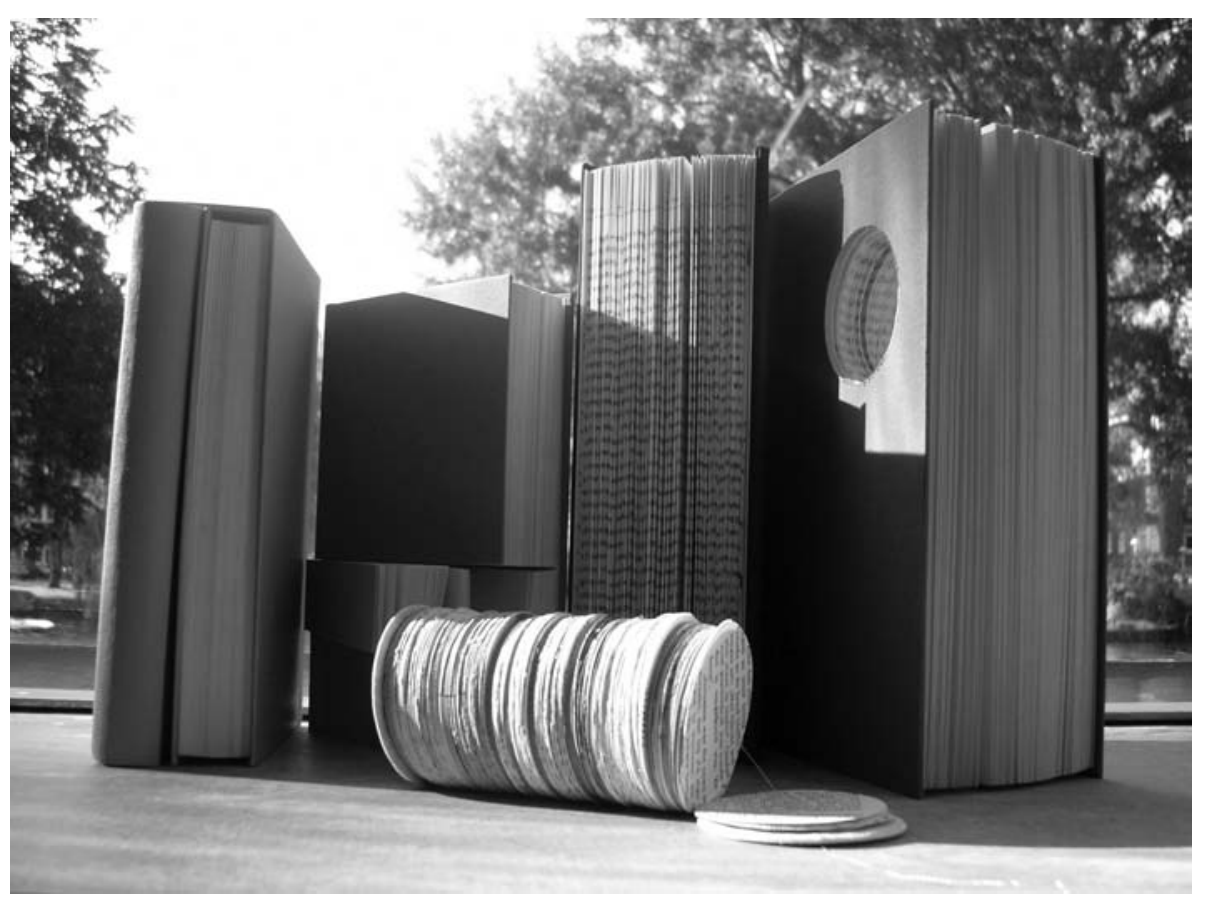

Fleur Thio: New ways of reading (2009)

"Which book suits you best? Are you a hasty reader, do you want to be eclectic and read small bits of many books or are you the slow reader that wants to take time to discover a book page by page?" 